\title{
Growth and other factors affecting peak expiratory flow rate
}

\author{
J W K CARSON, ${ }^{*}$ H HOEY,${ }^{*} \dagger$ AND M R H TAYLOR ${ }^{*} \dagger$ \\ ${ }^{*}$ National Children's Hospital and †Department of Paediatrics, Trinity College, Dublin
}

SUMMARY By means of a simple questionnaire and measurements of height, weight, and peak expiratory flow rates 3061 children from city and rural populations were studied. Children with asthma or other respiratory diseases had lower peak expiratory flow rates, and younger children living in rural areas had higher rates. In 2828 healthy children the peak expiratory flow rate increased with age, height, and weight. There was an increase in the slope of this line for both age and height -at 12 years and $145 \mathrm{~cm}$ in girls, and at 14 years and $155 \mathrm{~cm}$ in boys. This continued for two to three years and $15 \mathrm{~cm}$, respectively, before it declined. Previous surveys have obscured this change associated with height by reporting small numbers and using linear regression analysis. This type of analysis can underestimate the mean peak expiratory flow rate of small children by half to one standard deviation. A centile graph against age is recommended to describe normal values and their differences.

The Wright peak flow meter ${ }^{1}$ is a practical and common way of measuring peak expiratory flow rate. It is easy to use, even for 3 to 5 year old children. ${ }^{2}$ Lunn measured peak expiratory flow rate (PEFR) in over 3000 children, ${ }^{3}$ but his study was limited to city children aged 6 to 11 years; unhealthy children were not excluded and local air pollution was high. ${ }^{4}$ Other studies in normal children have been small and largely confined to city populations..$^{5-9}$ We report the results of a study comprising over 3000 children aged 4 to 18 years drawn from both city and rural populations.

\section{Subjects and methods}

Children at school in the city of Dublin (population about 800000 ), and smaller centres (population 5000-15000) within 60 miles of Dublin, were surveyed with their parents' consent. A questionnaire was distributed to the parents enquiring about chronic illnesses (table 1). Height was assessed with a portable stadiometer by the same investigator throughout the study. Weight in underclothes was measured with an electronic balance. PEFR was measured with a Wright flow meter. Four meters were used and were calibrated by one of the authors against the manufacturer's submaster meter which is used to calibrate all new meters before issue. After the method had been shown to a group of five children, each child had two or three practice blows, before three test blows done standing up with the neck held vertically and the tube of the meter held horizontally. The highest value reached was taken as the PEFR for that child. Social class was assessed according to the Registrar General's classification. ${ }^{10}$

\section{Results}

A total of 3061 children, 1528 boys and 1533 girls aged 4-19 years, were included in the analysis. Heights were not available for 79 children due to a fault in the stadiometer, and 233 children were excluded from the analysis of healthy children because of a chronic illness (assessed by the questionnaire), or an upper respiratory tract infection at the

Table 1 Questionnaire completed by parents

\begin{tabular}{|c|c|c|}
\hline Does your child have: & Please tick: & N \\
\hline 1 Asthma & () & $($ ) \\
\hline 2 Chronic chest infection & ( ) & ( ) \\
\hline 3 Coeliac disease (on gluten free diet) & ( ) & ( ) \\
\hline 4 Chronic kidney disease & ( ) & ( ) \\
\hline $\begin{array}{l}5 \text { Other long term illness requiring } \\
\text { regular hospital attendance: }\end{array}$ & () & ( ) \\
\hline Please name illness & & \\
\hline
\end{tabular}


time of study. Eighty seven boys and 49 girls had asthma ( $4.4 \%$ of the total) (table 2), and 63 (35 boys and 28 girls) had no asthma but either chronic chest infections, atopic symptoms, or an upper respiratory tract infection at the time of the study; 34 (11 boys and 23 girls) had other non-respiratory chronic illnesses. There was no predisposition to ill health in any social class. Asthma was commoner in the 1550 city children $(5 \cdot 1 \%)$ than in the 1511 rural children $(3 \cdot 8 \%)$ but this difference was not significant.

Children with asthma had a mean PEFR 18.4 $1 /$ minute lower than the healthy children $(p<0 \cdot 001)$. Those with other respiratory diseases had a mean PEFR 37.3 1/minute lower than the healthy children $(p<0 \cdot 001)$. Overall, rural children had a significantly higher mean PEFR (+3.81/minute) than those living in the city $(p=0.032)$. Similar

Table 2 Distribution by age and height of 135 asthmatic and 2847 non-asthmatic children

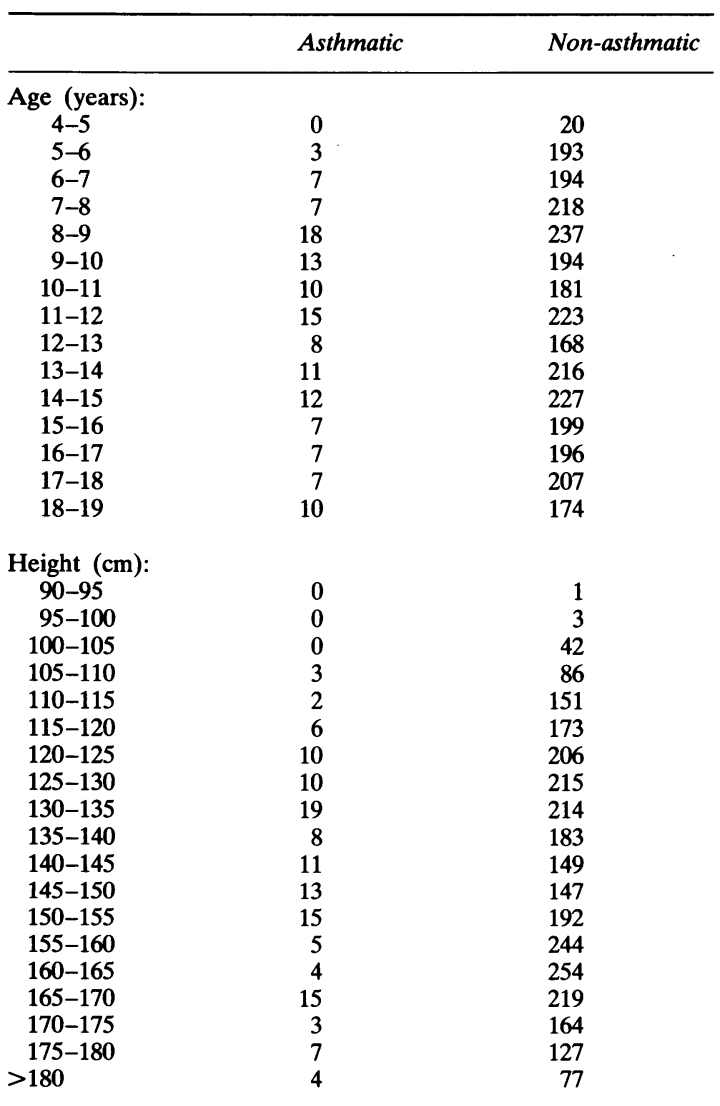

Values are greater than lower limits and less than or equal to upper limits for each group. analysis for children under 12 years, however, showed a greater difference $($ mean $+15.0 \mathrm{l} /$ minute for rural children), but in those over 12 years old rural children had a lower PEFR (mean -8.0 $1 /$ minute) than those living in the city.

Multilinear regression analysis of PEFR against the following independent variables was done: height, age and weight, rural dwelling, social class, asthma, other respiratory disease, and other nonrespiratory chronic disease (table 3 ). PEFR was not significantly associated with social class (whether taken as individual social classes or divided into two groups, manual and non-manual) or to non-respiratory chronic disease. Height, weight, age, and sex had a significant effect on PEFR $(p<0.001)$. Linear regression analysis on the groups studied are shown in table 4 .

There were 2828 healthy children, 1395 boys and 1433 girls, and the distribution of children by age is shown in table 5. The values for mean, standard deviation, and centiles of PEFR in age, height and weight groups are shown in tables 5, 6, and 7 . Among girls there was a significant increase in the slope of the PEFR/age line at 12 years, which continued for two years (fig 1). A similar increase was seen in the slope of the PEFR/height line starting at $145 \mathrm{~cm}$ and continuing for $15 \mathrm{~cm}$ (fig 2). In both cases the change in slope was significant $(p<0.0001)$. There was little increase in PEFR after this among girls. Among boys this change occurred at 14 years and at $155 \mathrm{~cm}$, and continued for similar periods (fig 1 and 2). There was continued increase in PEFR among boys up to 19 years of age.

When the healthy rural children were compared with city children of the same height (table 8) the boys had higher PEFRs up to a height of $145 \mathrm{~cm}$, and the girls from rural areas had higher PEFRs up to a height of $165 \mathrm{~cm}$. In the group from the rural areas, the smaller girls had similar or higher PEFRs to the boys up to a height of $165 \mathrm{~cm}$. When a similar comparison was made grouping the children by age

Table 3 Multilinear regression analysis of 2982 children with accurate details on all variables

\begin{tabular}{lcc}
\hline Variable & $\begin{array}{l}\text { Regression } \\
\text { coefficient }\end{array}$ & $\begin{array}{l}p \text { Value } \\
\text { (two tailed) }\end{array}$ \\
\hline Intercept & -143.8 & $<0.001$ \\
Height & +1.91 & $<0.001$ \\
Weight & +2.24 & $<0.001$ \\
Age & +11.01 & $<0.001$ \\
Male sex & +20.6 & $<0.001$ \\
Asthma & -18.4 & $<0.001$ \\
Other respiratory disease & -37.3 & $<0.001$ \\
From rural area & +3.81 & 0.032 \\
\hline
\end{tabular}


98 Carson, Hoey, and Taylor

Table 4 Linear regression analysis of PEFR against height

\begin{tabular}{|c|c|c|c|c|c|}
\hline & $a$ & $b$ & $\begin{array}{l}\text { No } \\
\text { of children }\end{array}$ & $\begin{array}{l}\text { Correlation } \\
\text { coefficient }\end{array}$ & $\begin{array}{l}\text { Standard error } \\
\text { of the estimate }\end{array}$ \\
\hline \multicolumn{6}{|c|}{ Healthy* } \\
\hline All (Boys & 5.5985 & $-439 \cdot 78$ & 1395 & 0.9151 & 56.75 \\
\hline$\{$ Girls & $5 \cdot 1903$ & $-390 \cdot 58$ & 1357 & 0.9053 & $47 \cdot 24$ \\
\hline \multicolumn{6}{|l|}{ Country } \\
\hline SBoys & $5 \cdot 2416$ & $-388 \cdot 85$ & 706 & 0.9086 & $55 \cdot 68$ \\
\hline \{Girls & $4 \cdot 9363$ & $-343 \cdot 42$ & 641 & $0 \cdot 9072$ & $44 \cdot 83$ \\
\hline \multicolumn{6}{|l|}{ City } \\
\hline SBoys & 5.9674 & $-493 \cdot 88$ & 689 & 0.9230 & $56 \cdot 65$ \\
\hline \{Girls & $5 \cdot 5611$ & $-454 \cdot 38$ & 716 & $0 \cdot 9165$ & $46 \cdot 11$ \\
\hline \multicolumn{6}{|c|}{ Healthy and unhealthy* } \\
\hline City & & & & & \\
\hline SBoys & $5 \cdot 9419$ & $-492 \cdot 55$ & 771 & 0.9193 & $57 \cdot 67$ \\
\hline |Girls & $5 \cdot 5551$ & $-454 \cdot 48$ & 779 & $0 \cdot 9145$ & $46 \cdot 74$ \\
\hline \multicolumn{6}{|c|}{ Healthy boys and girls togethert } \\
\hline City & $91 \cdot 3$ & $65 \cdot 858$ & 1405 & $0 \cdot 9213$ & $52 \cdot 32$ \\
\hline \multicolumn{6}{|c|}{ All healthy $\neq$} \\
\hline SBoys & 0.006760 & 1.5585 & 1395 & 0.9213 & 0.06564 \\
\hline |Girls & 0.007225 & 1.4883 & 1357 & $0 \cdot 8985$ & $0 \cdot 06845$ \\
\hline
\end{tabular}

${ }^{*} \mathrm{PEFR}=\mathrm{a} \times($ height in $\mathrm{cm})+\mathrm{b} ;$ †PEFR $=\mathrm{a} \times(\text { height in metres })^{3}+\mathrm{b}$; $\ddagger \log \mathrm{PEFR}=\mathrm{a} \times$ height $+\mathrm{b}$.

Table 5 Peak expiratory flow rates by age in centiles for 2828 healthy children

\begin{tabular}{|c|c|c|c|c|c|c|c|c|}
\hline \multirow{2}{*}{$\begin{array}{l}\text { Age } \\
\text { (years) }\end{array}$} & \multirow[t]{2}{*}{ Sex } & \multirow{2}{*}{$\begin{array}{l}\text { No of } \\
\text { children }\end{array}$} & \multirow{2}{*}{$\begin{array}{l}\text { Mean }(S D) \\
\text { peak expiratory } \\
\text { flow rate for } \\
\text { each group }\end{array}$} & \multicolumn{5}{|c|}{ Peak expiratory flow rate at: } \\
\hline & & & & $\begin{array}{l}97 \text { th } \\
\text { centile }\end{array}$ & $\begin{array}{l}90 \text { th } \\
\text { centile }\end{array}$ & $\begin{array}{l}50 t h \\
\text { centile }\end{array}$ & $\begin{array}{l}\text { 10th } \\
\text { centile }\end{array}$ & $\begin{array}{l}3 r d \\
\text { centile }\end{array}$ \\
\hline \multirow[t]{2}{*}{$4-5$} & $\mathbf{M}$ & 8 & $207(58)$ & 290 & 290 & 180 & 125 & 125 \\
\hline & $\mathbf{F}$ & 12 & $162(52)$ & 280 & 215 & 155 & 110 & 105 \\
\hline \multirow[t]{2}{*}{$5-6$} & $\mathbf{M}$ & 91 & $195(41)$ & 275 & 250 & 195 & 140 & 130 \\
\hline & $\mathbf{F}$ & 88 & $180(35)$ & 260 & 225 & 180 & 135 & 125 \\
\hline \multirow[t]{2}{*}{$6-7$} & $\mathbf{M}$ & 97 & 217 (39) & 290 & 270 & 215 & 165 & 145 \\
\hline & $\mathbf{F}$ & 91 & 198 (38) & 270 & 250 & 195 & 150 & 115 \\
\hline \multirow[t]{2}{*}{$7-8$} & $\mathbf{M}$ & 102 & $242(43)$ & 320 & 305 & 240 & 190 & 170 \\
\hline & $\mathbf{F}$ & 109 & 231 (37) & 295 & 280 & 230 & 185 & 155 \\
\hline \multirow[t]{2}{*}{$8-9$} & $\mathbf{M}$ & 112 & $276(45)$ & 350 & 330 & 280 & 210 & 195 \\
\hline & $\mathbf{F}$ & 119 & $258(39)$ & 350 & 320 & 250 & 215 & 200 \\
\hline \multirow[t]{2}{*}{$9-10$} & $\mathbf{M}$ & 90 & 306 (49) & 390 & 375 & 300 & 245 & 205 \\
\hline & $\mathbf{F}$ & 98 & 290 (39) & 345 & 340 & 285 & 235 & 215 \\
\hline \multirow[t]{2}{*}{$10-11$} & $\mathbf{M}$ & 79 & $325(45)$ & 405 & 380 & 335 & 250 & 235 \\
\hline & $\mathbf{F}$ & 95 & 305 (42) & 375 & 355 & 300 & 245 & 235 \\
\hline \multirow[t]{2}{*}{$11-12$} & $\mathbf{M}$ & 100 & 353 (48) & 425 & 405 & 355 & 290 & 245 \\
\hline & $F$ & 115 & 333 (47) & 410 & 385 & 335 & 265 & 250 \\
\hline \multirow[t]{2}{*}{$12-13$} & $\mathbf{M}$ & 88 & 377 (47) & 485 & 430 & 375 & 310 & 300 \\
\hline & $\mathbf{F}$ & 103 & 369 (49) & 450 & 435 & 370 & 305 & 275 \\
\hline \multirow[t]{2}{*}{$13-14$} & $\mathbf{M}$ & 116 & $404(60)$ & 525 & 495 & 405 & 330 & 300 \\
\hline & $\mathbf{F}$ & 109 & 421 (48) & 505 & 490 & 425 & 355 & 340 \\
\hline \multirow[t]{2}{*}{$14-15$} & $\mathbf{M}$ & 100 & $450(64)$ & 570 & 535 & 445 & 365 & 335 \\
\hline & $\mathbf{F}$ & 135 & $440(46)$ & 520 & 500 & 440 & 385 & 355 \\
\hline \multirow[t]{2}{*}{$15-16$} & $\mathbf{M}$ & 107 & 499 (72) & 615 & 595 & 505 & 400 & 340 \\
\hline & $\mathbf{F}$ & 93 & 448 (51) & 545 & 510 & 450 & 385 & 350 \\
\hline \multirow[t]{2}{*}{$16-17$} & $\mathbf{M}$ & 101 & $552(63)$ & 650 & 620 & 565 & 475 & 400 \\
\hline & $\mathbf{F}$ & 97 & $460(45)$ & 550 & 525 & 455 & 400 & 390 \\
\hline \multirow[t]{2}{*}{$17-18$} & $\mathbf{M}$ & 109 & $569(66)$ & 695 & 640 & 570 & 480 & 430 \\
\hline & $\mathbf{F}$ & 94 & 468 (49) & 550 & 525 & 475 & 405 & 370 \\
\hline \multirow[t]{2}{*}{$18-19$} & $\mathbf{M}$ & 95 & $602(64)$ & 720 & 690 & 605 & 515 & 485 \\
\hline & $\mathbf{F}$ & 75 & $478(47)$ & 555 & 535 & 485 & 420 & 380 \\
\hline
\end{tabular}

Figures given as unsmoothed values. Values are greater than lower limit and less than or equal to upper limit for each group. 
Table 6 Peak expiratory flow rates by height for 2752 healthy children. Figures are shown for boys/girls

\begin{tabular}{|c|c|c|c|c|c|}
\hline \multirow{2}{*}{$\begin{array}{l}\text { Height } \\
(\mathrm{cm})\end{array}$} & \multirow{2}{*}{$\begin{array}{l}\text { No of } \\
\text { children }\end{array}$} & \multirow{2}{*}{$\begin{array}{l}\text { Mean }(S D) \\
\text { peak expiratory } \\
\text { flow rate for } \\
\text { each group }\end{array}$} & \multicolumn{3}{|c|}{ Mean peak expiratory flow rate at: } \\
\hline & & & $\begin{array}{l}90 \text { th } \\
\text { centile }\end{array}$ & $\begin{array}{l}\text { 50th } \\
\text { centile }\end{array}$ & $\begin{array}{l}\text { 10th } \\
\text { centile }\end{array}$ \\
\hline $90-95$ & $1 / 0$ & $131 / 0$ & $0 / 0$ & $0 / 0$ & $0 / 0$ \\
\hline $95-100$ & $1 / 2$ & $170 / 188(0 / 54)$ & $0 / 0$ & $0 / 0$ & $0 / 0$ \\
\hline $100-105$ & $18 / 22$ & $168 / 161(30 / 35)$ & $210 / 190$ & $165 / 175$ & $125 / 115$ \\
\hline $110-115$ & $65 / 79$ & $206 / 194(40 / 37)$ & $255 / 240$ & $205 / 195$ & $160 / 155$ \\
\hline $115-120$ & $79 / 86$ & $222 / 214(44 / 46)$ & $260 / 260$ & $210 / 210$ & $185 / 160$ \\
\hline $120-125$ & $95 / 106$ & $250 / 244(42 / 41)$ & $305 / 290$ & $250 / 240$ & $195 / 195$ \\
\hline $125-130$ & $90 / 116$ & $269 / 273(43 / 43)$ & $320 / 335$ & $270 / 270$ & $210 / 220$ \\
\hline $130-135$ & $96 / 112$ & $297 / 299(49 / 51)$ & $355 / 360$ & $305 / 290$ & $240 / 235$ \\
\hline $135-140$ & $80 / 94$ & $326 / 308(41 / 44)$ & $385 / 360$ & $330 / 305$ & $265 / 250$ \\
\hline $140-145$ & $77 / 67$ & $344 / 332(41 / 52)$ & $390 / 395$ & $350 / 335$ & $280 / 265$ \\
\hline $145-150$ & $87 / 57$ & $365 / 370(38 / 52)$ & $415 / 440$ & $365 / 370$ & $310 / 305$ \\
\hline $155-160$ & $71 / 167$ & $412 / 443(54 / 46)$ & $485 / 510$ & $415 / 445$ & $345 / 385$ \\
\hline $160-165$ & $75 / 171$ & $469 / 457(72 / 51)$ & $575 / 520$ & $460 / 460$ & $395 / 390$ \\
\hline $165-170$ & $111 / 99$ & $514 / 470(77 / 48)$ & $605 / 525$ & $515 / 470$ & $420 / 405$ \\
\hline $170-175$ & $129 / 30$ & $545 / 484(69 / 47)$ & $635 / 525$ & $545 / 490$ & $455 / 420$ \\
\hline $175-180$ & $118 / 8$ & $568 / 493(69 / 53)$ & $660 / 0$ & $570 / 0$ & $485 / 0$ \\
\hline$>180$ & $72 / 2$ & $584 / 474(69 / 6)$ & $675 / 0$ & $585 / 0$ & $510 / 0$ \\
\hline
\end{tabular}

Figures given as unsmoothed values.

Table 7 Peak expiratory flow rates, by weight for 2828 healthy children. Figures are shown for boys/girls

\begin{tabular}{|c|c|c|c|c|c|}
\hline \multirow{2}{*}{$\begin{array}{l}\text { Weight } \\
(\mathrm{kg})\end{array}$} & \multirow{2}{*}{$\begin{array}{l}\text { No of } \\
\text { children }\end{array}$} & \multirow{2}{*}{$\begin{array}{l}\text { Mean }(S D) \\
\text { peak expiratory } \\
\text { flow rate for } \\
\text { each group }\end{array}$} & \multicolumn{3}{|c|}{ Mean peak expiratory flow rate at: } \\
\hline & & & $\begin{array}{l}\text { 90th } \\
\text { centile }\end{array}$ & $\begin{array}{l}\text { 50th } \\
\text { centile }\end{array}$ & $\begin{array}{l}\text { 10th } \\
\text { centile }\end{array}$ \\
\hline$<15$ & $2 / 2$ & $179 / 163(67 / 19)$ & $0 / 0$ & $0 / 0$ & $0 / 0$ \\
\hline $15-20$ & $103 / 108$ & $191 / 185(38 / 47)$ & $250 / 235$ & $190 / 180$ & $145 / 130$ \\
\hline $20-25$ & $197 / 221$ & $237 / 225(43 / 47)$ & $290 / 280$ & $235 / 225$ & $180 / 165$ \\
\hline $25-30$ & $183 / 202$ & $287 / 274(52 / 46)$ & $355 / 335$ & $290 / 270$ & $220 / 215$ \\
\hline $30-35$ & $143 / 135$ & $328 / 318(50 / 50)$ & $390 / 385$ & $335 / 310$ & $255 / 255$ \\
\hline $35-40$ & $121 / 113$ & $370 / 347(48 / 49)$ & $430 / 400$ & $365 / 355$ & $310 / 275$ \\
\hline $40-45$ & $98 / 113$ & $391 / 400(51 / 53)$ & $455 / 470$ & $385 / 400$ & $335 / 330$ \\
\hline $45-50$ & $80 / 148$ & $430 / 431(69 / 53)$ & $515 / 505$ & $430 / 430$ & $340 / 365$ \\
\hline $50-55$ & $97 / 159$ & $480 / 449(70 / 48)$ & $575 / 510$ & $485 / 445$ & $400 / 390$ \\
\hline $55-60$ & $106 / 114$ & $526 / 465(70 / 52)$ & $605 / 525$ & $535 / 470$ & $425 / 405$ \\
\hline $60-65$ & $107 / 70$ & $551 / 471(72 / 48)$ & $630 / 520$ & $560 / 475$ & $445 / 410$ \\
\hline $65-70$ & $78 / 31$ & $592 / 471(63 / 38)$ & $685 / 510$ & $590 / 470$ & $520 / 425$ \\
\hline $70-75$ & $46 / 13$ & $589 / 486(65 / 52)$ & $680 / 0$ & $585 / 0$ & $505 / 0$ \\
\hline $75-80$ & $18 / 3$ & $553 / 480(73 / 47)$ & $645 / 0$ & $540 / 0$ & $440 / 0$ \\
\hline $80-85$ & $9 / 0$ & $610 / 0 \quad(71 / 0)$ & $0 / 0$ & $0 / 0$ & $0 / 0$ \\
\hline$>85$ & $7 / 1$ & $610 / 464(71 / 0)$ & $0 / 0$ & $0 / 0$ & $0 / 0$ \\
\hline
\end{tabular}

Figures given as unsmoothed values.

instead of height, however, there was little difference between the rural and city children.

\section{Discussion}

Our results confirm that children with respiratory disease have lower values of PEFR than normal children. Those children with respiratory disease but no history of asthma had a particularly low mean
PEFR, which suggests that some of these children had asthma and were not getting appropriate treatment. $^{11}$

Although our study showed a significantly higher mean PEFR in the rural children, this difference was greater among the children under 12 years. The inclusion of older rural children as boarders in the city secondary schools may have increased the level of PEFR in these older age groups, but we have no 


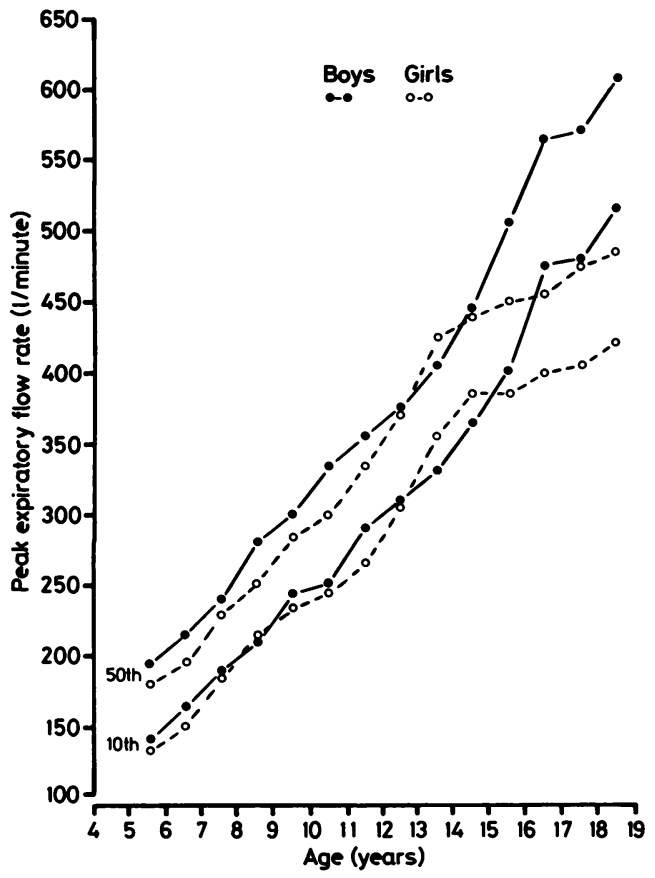

Fig 1 Peak expiratory flow rate and age, 10th and 50th centile lines (unsmoothed values).

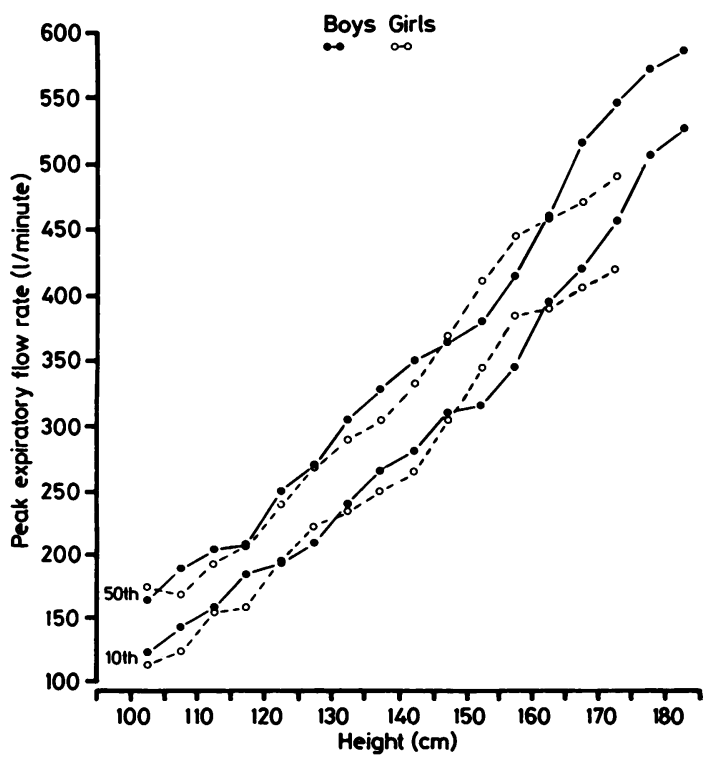

Fig 2 Peak expiratory flow rate and height, 10th and 50th centile lines (unsmoothed values). record of the numbers of rural boarders in city schools. Air pollution may have been another factor.

The median smoke levels in Dublin at the time of the study were between $25-80 \mu \mathrm{g} / \mathrm{m}^{3}{ }^{12}$ In Sheffield (where Lunn's study was carried out) the mean daily figures in the winter $1965-6$ were $97-301 \mu \mathrm{g} / \mathrm{m}^{3}$. The lower air pollution and the inclusion or rural children boarding in city schools in the present study may account for the higher PEFR values in the city children when compared with the results from Sheffield and with the other studies of city children in the 1960s (table 9). In addition the Sheffield study did not exclude unhealthy children.

When the results of the study by Godfrey et $^{\mathrm{al}} \mathrm{l}^{7}$ are compared with our results for city children analysed in the same way (linear regression) the results are similar in the younger children (table 9). There is good correlation for the girls throughout, and for boys below $135 \mathrm{~cm}$ in height. Above this, the difference increased from 21 to $45 \mathrm{l} /$ minute. Not all the differences can be satisfactorily explained. Factors such as smoking by the children or their parents were not assessed in either study. Genetic differences as shown by measurement of lung volumes of children of different races ${ }^{13}$ may also be a factor.

In this study the centile method of analysis gives a much higher mean value for PEFR in small and tall children than linear regression. Linear regression might give a poor estimate of central tendency at the extremes of the data and would also conceal the peripubertal acceleration. The linear regression method underestimates the PEFR in small children by $30 \mathrm{l} /$ minute for boys and $19 \mathrm{l} /$ minute for girls. These differences are close to one standard deviation for boys and half a standard deviation for girls. There are similar but smaller differences among taller children, where the regression analysis underestimates the value for boys and overestimates the value for girls (table 9). Smoothing for centile lines also has the disadvantage of concealing the peripubertal acceleration.

In other smaller studies the results have been presented as a linear correlation with height $t^{5-8}$ or as an exponential of height. ${ }^{89}$ The PEFR/height graphs of Nairn et $a l^{5}$ showed a similar pattern to our results, but they used a linear regression analysis relating PEFR to height as have many studies of forced expiratory volume in one second, ${ }^{5-7}$ which have shown a similar pattern in their graphs. ${ }^{14} 15$

This is the largest study of PEFR in healthy children so far reported. The results show that changes take place in PEFR about the time of puberty but are not in phase with other growth changes. These changes have been obscured in 
Table 8 Mean peak expiratory flow rates of 2752 healthy children by height and where they lived. Figures are shown for boys/girls

\begin{tabular}{|c|c|c|c|c|c|}
\hline \multirow{2}{*}{$\begin{array}{l}\text { Height } \\
\text { (cm) }\end{array}$} & \multicolumn{2}{|c|}{ Children living in city $(n=1409)$} & \multicolumn{2}{|c|}{ Children living in rural areas $(n=1343)$} & \multirow{2}{*}{$\begin{array}{l}\text { Difference between } \\
\text { mean peak expiratory } \\
\text { flow rate in rural } \\
\text { and city children }\end{array}$} \\
\hline & No of children & $\begin{array}{l}\text { Mean peak } \\
\text { expiratory } \\
\text { flow rate }\end{array}$ & No of children & $\begin{array}{l}\text { Mean peak } \\
\text { expiratory } \\
\text { flow rate }\end{array}$ & \\
\hline $90-95$ & $1 / 0$ & $131 / 0$ & $0 / 0$ & $0 / 0$ & $0 / 0$ \\
\hline $95-100$ & $1 / 2$ & $170 / 188$ & $0 / 0$ & $0 / 0$ & $0 / 0$ \\
\hline $100-105$ & $5 / 8$ & $155 / 135$ & $13 / 14$ & $173 / 175$ & $18 / 40$ \\
\hline $105-110$ & $18 / 18$ & $173 / 159$ & $23 / 23$ & $208 / 186$ & $35 / 27$ \\
\hline $110-115$ & $30 / 40$ & $197 / 180$ & $35 / 39$ & $213 / 209$ & $-2 / 41$ \\
\hline $115-120$ & $39 / 41$ & $223 / 192$ & $40 / 45$ & $221 / 233$ & $22 / 34$ \\
\hline $120-125$ & $37 / 50$ & $236 / 226$ & $58 / 56$ & $258 / 260$ & $11 / 29$ \\
\hline $125-130$ & $42 / 47$ & $263 / 256$ & $48 / 69$ & $274 / 285$ & $11 / 29$ \\
\hline $130-135$ & $45 / 50$ & $289 / 276$ & $51 / 62$ & $305 / 316$ & $16 / 40$ \\
\hline $135-140$ & $38 / 48$ & $323 / 292$ & $42 / 46$ & $328 / 325$ & $5 / 33$ \\
\hline $140-145$ & $41 / 44$ & $342 / 322$ & $36 / 23$ & $346 / 350$ & $4 / 28$ \\
\hline $145-150$ & $42 / 33$ & $365 / 357$ & $45 / 24$ & $365 / 387$ & $0 / 30$ \\
\hline $150-155$ & $43 / 64$ & $386 / 405$ & $46 / 34$ & $378 / 417$ & $-8 / 12$ \\
\hline $155-160$ & $35 / 98$ & $421 / 438$ & $36 / 69$ & $404 / 449$ & $-17 / 11$ \\
\hline $160-165$ & $46 / 89$ & $475 / 454$ & $29 / 82$ & $460 / 459$ & $-15 / 5$ \\
\hline $165-170$ & $55 / 64$ & $517 / 470$ & $56 / 35$ & $511 / 470$ & $-6 / 0$ \\
\hline $170-175$ & $63 / 17$ & $555 / 482$ & $66 / 13$ & $535 / 487$ & $-20 /-5$ \\
\hline $175-180$ & $64 / 3$ & $581 / 485$ & $54 / 5$ & $553 / 498$ & $-28 / 13$ \\
\hline$>180$ & $46 / 2$ & $593 / 474$ & $26 / 0$ & $568 / 0$ & $-25 / 0$ \\
\hline
\end{tabular}

Table 9 Expected values of PEFR for given height according to different sources and methods of analysis (boys/girls)

\begin{tabular}{|c|c|c|c|c|c|c|}
\hline & \multirow{2}{*}{$\begin{array}{l}\text { Total } \\
\text { No }\end{array}$} & \multicolumn{5}{|c|}{ Height $(\mathrm{cm})$} \\
\hline & & 105 & 115 & 135 & 155 & 170 \\
\hline \multicolumn{7}{|l|}{ This study } \\
\hline Centile chart & 2752 & $178 / 173$ & $208 / 203$ & $318 / 298$ & $400 / 428$ & $530 / 480$ \\
\hline Linear regression & 2752 & $148 / 154$ & $204 / 206$ & $316 / 310$ & $428 / 414$ & $512 / 492$ \\
\hline Healthy in rural areas* & 1347 & $162 / 175$ & $214 / 224$ & $319 / 323$ & $424 / 422$ & $502 / 496$ \\
\hline \multicolumn{7}{|l|}{ Healthy in cities* } \\
\hline This study & 1405 & $133 / 130$ & $192 / 185$ & $312 / 296$ & $431 / 408$ & $521 / 491$ \\
\hline Godfrey et $a^{7}$ & 382 & $132 / 132$ & $185 / 185$ & $291 / 290$ & $397 / 396$ & $476 / 475$ \\
\hline Murray and Cook ${ }^{8}$ & 220 & $120 / 144$ & $178 / 191$ & $290 / 284$ & $404 / 377$ & $490 / 447$ \\
\hline $\begin{array}{l}\text { Weng and Levison } \\
\text { (boys and girls combined) }\end{array}$ & 139 & 139 & 185 & 283 & 381 & 454 \\
\hline \multicolumn{7}{|l|}{ Healthy and unhealthy in cities* } \\
\hline This study & 1347 & $131 / 128$ & $191 / 184$ & $310 / 295$ & $428 / 407$ & $518 / 490$ \\
\hline Lunn $^{3}$ & 3556 & - & $175 / 167$ & $254 / 251$ & - & - \\
\hline \multicolumn{7}{|c|}{ Healthy in cities $\dagger$ (boys/girls combined) } \\
\hline This study & 1405 & 172 & 205 & 290 & 406 & 514 \\
\hline Bjure et $a l^{9}$ & 214 & - & 206 & 274 & 365 & 451 \\
\hline
\end{tabular}

${ }^{*}$ Linear regression; tlinear regression based on height in $\mathrm{m}^{3}$.

previous studies by the types of analysis used. The timing of the increase in the slope of the PEFR against age, height, or weight lines may depend on the timing of puberty, and this varies in different countries. The mean (SD) age of menarche for Irish girls is $13.5(1 \cdot 3)$ years. ${ }^{16}$ In the girls in this study the spurt in PEFR overlaps the menarche, and so follows the height spurt that normally precedes the menarche.
In view of these findings we suggest that a 'centile chart' approach to normal values of PEFR is a more appropriate representation of normal values than the conventional straight line graph usually used for children. A centile chart is the accepted method of presenting normal values for height and weight, and it seems sensible to apply it to pulmonary function as well. Charts of PEFR for age (figs 3 and 4 based on table 5) rather than height are probably more 


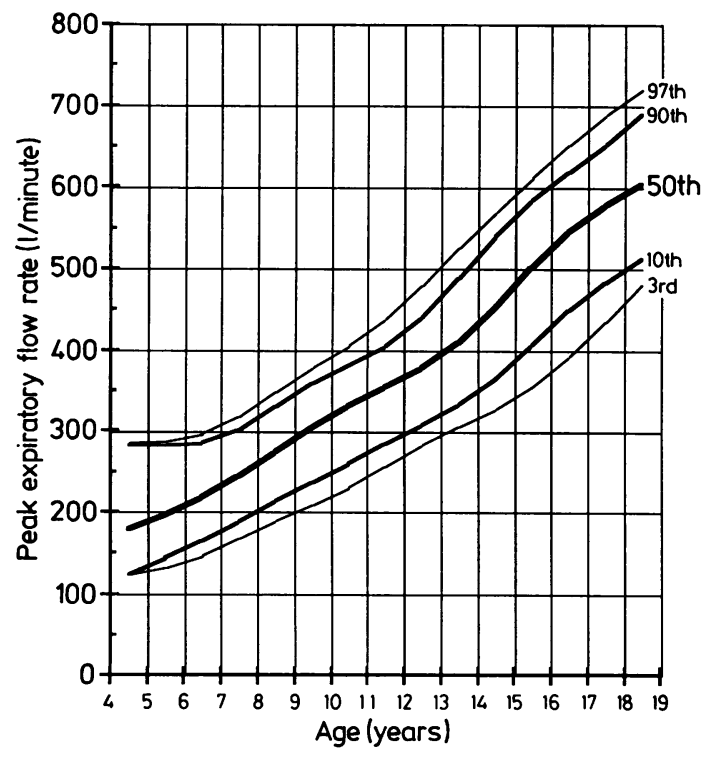

Fig 3 Peak expiratory flow rate and age; centile chart for boys (smoothed values).

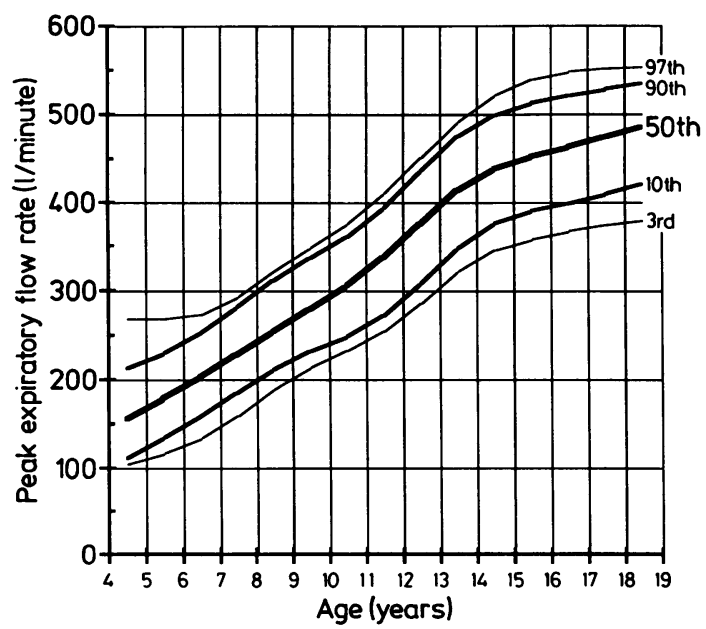

Fig 4 Peak expiratory flow rate and age; centile chart for girls (smoothed values). convenient for rapid reference in an accident and emergency department or a busy general practice when accurate heights are not readily available.

We thank the children, their parents, and their teachers whose cooperation was essential for the completion of this study, as well as our many helpers in the National Children's Hospital and Trinity College, Dublin.

\section{References}

${ }^{1}$ Wright BM, McKerrow CB. Maximum forced expiratory flow rate as a measure of ventilatory capacity. $\mathrm{Br}$ Med J 1959;ii: 1041-7.

2 Milner AD, Ingram D. Peak expiratory flow rates in children under 5 years of age. Arch Dis Child 1970;45:780-2.

${ }^{3}$ Lunn JE. Respiratory measurements of 3,556 Sheffield schoolchildren. British Journal of Preventive and Social Medicine 1965;19:115-22.

${ }^{4}$ Lunn JE, Knowelden J, Handyside AJ. Patterns of respiratory illness in Sheffield infant schoolchildren. British Journal of Preventive and Social Medicine 1967;21:7-16.

5 Nairn JR, Bennett AJ, Andrew JD, MacArthur P. A study of respiratory function in normal school children. Arch Dis Child 1962;36:253-8.

${ }^{6}$ Weng T-R, Levison H. Standards of pulmonary function in children. Am Rev Respir Dis 1969;99:879-94.

${ }^{7}$ Godfrey S, Kamburoff PL, Nairn JR. Spirometry, lung volumes and airway resistance in normal children aged 5 to 18 years. $\mathrm{Br} \mathrm{J}$ Dis Chest 1970;64:15-24.

${ }^{8}$ Murray AB, Cook CD. Measurement of peak expiratory flow rates in 220 normal children from 4.5 to 18.5 years of age. J Pediatr 1963;62:186-9.

${ }^{9}$ Bjure J, Dalen G, Kjellman B. Peak expiratory flow rate. Reference values for Swedish children. Acta Paediatr Scand 1979;68:605-7.

10 Registrar General. Classification of occupations 1970. London: HMSO, 1971.

1 Speight ANP, Lee DA, Hey EN. Underdiagnosis and undertreatment of asthma in childhood. $\mathrm{Br}$ Med $J$ 1983;286:1253-6.

12 Riley P. Environment pollution report 1983/4. Dublin: Health inspectorate, atmospheric pollution and noise control unit, Dublin Corporation, 1984.

${ }^{13}$ Binder RE, Mitchell CA, Schoenberg JB, Bouhuys A. Lung function among black and white children. Am Rev Respir Dis 1976;114:955-9.

14 Strang LB. The ventilatory capacity of normal children. Thorax 1959;14:305-10.

15 Dickman ML, Schmidt CD, Gardner RM. Spirometric standards for normal children and adolescents (ages 5 years through 18 years). Am Rev Respir Dis 1971;104:680-7.

${ }^{16}$ Hoey H, Cox L, Tanner J. The age of menarche in Irish girls. Ir Med J 1986;79:283-5.

Correspondence to Dr JWK Carson, National Children's Hospital, Harcourt Street, Dublin 2, Ireland.

Accepted 14 June 1988 